Logos Universality Mentality Education Novelty, Section: Social Sciences

ISSN: $2284-5747$ (print), ISSN: $2284-5747$

(electronic)

Covered in: CEEOL, Index Copernicus, Ideas

RePeC, EconPapers, Socionet

\title{
THE ABANDONMENT OF CHILDREN WITH 0-3 YEARS IN ROMANIA - INSTITUTIONALIZATION AND ISSUE
}

Rebeca POPESCU

Logos Universality Mentality Education Novelty, Section: Social Sciences, 2014, Year III, Issue 1, pp: 129-137

Published by:

Lumen Publishing House

On behalf of:

Lumen Research Center in Social and Humanistic Sciences 


\title{
The Abandonment of Children with 0-3 years in Romania - Institutionalization and Issues
}

\author{
Rebeca POPESCU1
}

\begin{abstract}
In the context of this paper, the term abandon refers to a situation in which the child is left by his parents in hospitals or other institutions and different places. It can be a period of several days or even years in which parents are not interested in the concrete situation of their children and do not visit them. In Romania, in 2013, according to the Ministry of Labour, Family and Social Protection, there were a significant number of children abandoned in maternities, respectively 915, representing 63\% from all children abandoned in hospitals. Facing poverty, exacerbated by the economic crisis, many parents have understood to respond to this situation by not assuming the role of a parent and they abandoned their own child. Abandonment due to poverty is not a new phenomenon and was covered immediately after the 1989 Romanian Revolution, when images with institutionalized children revealed the amplitude and consequences of the phenomenon. The child protection policy focused in the years following the revolution to the deinstitutionalization, but even today there are parents who leave their children in the care of hospitals and various social institutions. Studies have revealed adverse effects on psychological development and social integration of abandoned or institutionalized children, and therefore it is necessary to educate parents to identify alternatives to abandonment. Abandon prevention policies may be found in subsequent years increasing number of centers specialized in working with parents/mother and child, like maternal centers, day centers, centers/offices for counseling parents and children, and the success of these policies mean steady decrease in the number of children abandoned in hospitals or placed in foster care.
\end{abstract}

\section{Keywords:}

children abandon, institutionalization, poverty, Romania.

${ }^{1} \mathrm{Ph}$. D candidate, Sociology, University of Bucharest, Faculty of Sociology and Social Work, 9, Schitu Măgureanu Street, district 5, Bucharest, Romania, rebecapopescu@yahoo.com.

Popescu, R. (2014). The Abandonment of Children with 0-3 years in Romania - Institutionalization and Issues. Logos Universality Mentality Education Novelty, Section: Social Sciemces, Year III, Issue 1, 2014, pp. 129-137 


\section{Introduction}

The abandonment of children has taken various forms over the years, in all historical periods (Gill, 2014). Starting in the 19th century the abandonment has become a phenomenon against which Governments around the world have begun to fight (Segalen, 2011). Romania and China have remained however in the world spotlight as a result of the policy taken for birth promotion Romania case and for restrictive measures aimed at reducing birth rate - the case of China (Feng, 2005).

In Romania of the 19th century, "the sudden and temporary increase of fertility was followed by a large increase in the number of abandon children in orphanages, as abandoned as children that were meant to shelter them and whose fate worthy of pity was discovered by Western countries on the occasion of the fall of communism". (Segalen, 2011: 366 - author translation).

In addition to poverty, (Segalen, 2011), in Romania, the abandonment was favored by a complex of factors such as population exhaustion and perverse misinformation. This situation has led to the institutionalization of abandonment and overpopulation of Centers for Children (named House of Children), in the last year of the regime being more children than beds in state institutions empowered to care for them (Kligman, 2000).

\section{Consequences of long-term institutionalization}

Children institutionalized in the Communist regime become young remained a vulnerable group, in terms of professional experience and of dependency on social welfare system. They do not have the skills of independent living and have less developed social basic skills (the ability to identify and solve problems, the ability to work in groups, ability to face tensions, to make decisions, to manage budgets, to communicate, etc.)" (Buțiu, 2011, 10).

Studies show that post institutionalized young people are a group vulnerable to, on the one hand due to the reticence of employers, and on the other hand due to the fact that they don't have the skills for independent living. (Buțiu, 2011).

Also from the point of view of primary socialization, in institution, the children attachment for different people is strongly influenced by the conditions of residence and the changes, either by changing the staff, either by moving from one institution to another, as age and/or the state of physical and mental health (from the children's swing/Center for children 0-3 years in to Foster care/Placement center for different age groups and/or physical or mental disorders until adulthood). 
The Placement Centers are included by Goffman in the total institution group, institutions group for the "powerless, but harmless" (Goffman, 2004: 16 - author translation). In total institutions "he lives with all its aspects inside the institution, in the proximity of other individuals as isolated by the out world" (Goffman, 2004: 179 - author translation). This has happened to children who were abandoned in institutions by their parents. Here is the message that accompany an image of the conditions in the Orphanages/Placement Centers, posted on site ziare.com: "Immediately after the Revolution of ' 89 , the country orphanages were full of unwanted children; too scarce/pittance and too small for a human living, in these places it was seen the most clearly that the rough legacy of Communism fell, in particular, on the shoulders of children leaved/abandoned because of pro-birth policy" (author translation from http://www.ziare.com/social/romani/copiii-parasiti-ai-romaniei-inca-inumbra-regimului-comunist-1223034).

\section{Child abandonment after the 1990s}

Unfortunately a part of the "harmful practices" for children in orphanages has remained subsequent after Revolution, and the effects of institutionalization of communism regime have been described by several researchers (Marshall et al., 2004; McLaughlin et al., 2012; Polvere, 2011). Longitudinal studies carried out in Bucharest, as part of The Bucharest Early Intervention Project, which began in 1999, 10 years after the Romanian Revolution, pointing out problems, physical and social health of the institutions children: delays, anxiety disorders, attention deficit, repetitive behaviors, issues of attachment and low intelligence. The adverse effects of the placement, as well as the risk to escape from the institution-loitering, departure from the system of protection without education or employment, leaves of opportunities young to gain significant work experience, and residential treatment has often been criticized for excessive use. (Polvere, 2011: 321).

Those studies that have assessed the consequences of the abandonment of children and contributed to the implementation of policies for the abandon prevention, are resulting in several legislative provisions.

The first steps that have been taken have been referred to the efforts being undertaken deinstitutionalization, (Greenwell, 2000) in two ways. The first sense was disbanding of large centers for children, and the second was meant to promote the maintenance of family ties, being on the one hand stepped up visits between relatives, and on the other hand being made for the children less than 3 years to be placed in foster families. These measures were designed to facilitate the social reintegration of children and family. 
Once the Law no. 272/2004 have been established, there has been completed the alternative measures of protection, designed to facilitate the maintenance of the child in the family. According to article 55 of Law no. $272 / 2004$ on the protection and promotion of the rights of the child, the State grants special protection to "a child temporarily or permanently deprived of the protection of his parents until a full exercise capacity acquisition". According to article 64 from the same Law, the child under two years old can be placed "only at extended family or foster family, its placement in a residential care service being prohibited", with exception of the disabilities children. Also, according to the same article, the State should keep siblings together.

\section{Research methods}

It was carried out an secondary analysis (Chelcea, 2007) of the data from the period 2002-2013 for children aged between 0 and 3 years old, institutionalized in public orphanages and those who leave temporarily in hospital units. It was envisaged that these children represent the most vulnerable category in terms of long-term consequences of institutionalization and from the point of view of the family reintegration possibilities. The data was taken from the website of the Romanian Ministry of Labour, Family and Social Protection. There have been not used the previous year 2002 data, as it has been identified only a single graph, which covers the period 1999-2004, but did not distinguish between children from public foster care institutions and those who are in private foster care institutions.

It was discussed especially the situation of children 0-3 years, because they are the most vulnerable in the situation when they are abandoned and also, because long term consequences for the reintegration possibilities and regarding the serious attachment disorders.

Table 1. Children in Public Foster Care Centers during the period 2002-2013

\begin{tabular}{|l|l|l|l|l|l|l|l|l|}
\hline & $\begin{array}{c}\text { Under 1 } \\
\text { year }\end{array}$ & $\begin{array}{c}1-2 \\
\text { years }\end{array}$ & $\begin{array}{c}3-6 \\
\text { years }\end{array}$ & $\begin{array}{c}7-9 \\
\text { years }\end{array}$ & $\begin{array}{c}10-13 \\
\text { years }\end{array}$ & $\begin{array}{c}14-17 \\
\text { years }\end{array}$ & $\begin{array}{c}\text { Over } \\
18 \text { years }\end{array}$ & Total \\
\hline 2002 & 1,028 & 1,318 & 2,164 & 3,412 & 9,573 & 15,356 & 4,430 & 37,781 \\
\hline 2003 & 619 & 889 & 1,730 & 2,865 & 7,457 & 13,562 & 5,049 & 32,171 \\
\hline 2004 & 468 & 541 & 1,552 & 2,655 & 6,075 & 11,061 & 5,227 & 27,579 \\
\hline 2005 & 123 & 323 & 1,395 & 2,210 & 4,941 & 8,896 & 5,796 & 23,684 \\
\hline 2006 & 98 & 250 & 1,269 & 1,905 & 4,415 & 7,421 & 5,840 & 21,198 \\
\hline 2007 & 226 & 316 & 1,492 & 1,949 & 4,325 & 6,570 & 5,654 & 20,532 \\
\hline 2008 & 236 & 332 & 1,521 & 2,150 & 4,303 & 6,245 & 5,246 & 20,033 \\
\hline 2009 & 232 & 343 & 1,476 & 2,294 & 4,396 & 5,939 & 4,845 & 19,525 \\
\hline
\end{tabular}




\begin{tabular}{|l|l|l|l|l|l|l|l|l|}
\hline 2010 & 246 & 395 & 1,541 & 2,327 & 4,473 & 5,760 & 4,384 & 19,126 \\
\hline 2011 & 260 & 427 & 1,608 & 2,436 & 4,639 & 5,810 & 4,035 & 19,215 \\
\hline 2012 & 257 & 421 & 1,702 & 2,415 & 4,926 & 5,697 & 3,375 & 18,793 \\
\hline 2013 & 273 & 425 & 1,687 & 2,307 & 4,839 & 5,742 & 2,875 & 18,148 \\
\hline
\end{tabular}

Source: Ministry of Labour, Family and Social Protection, http://www.copii.ro/Statistici,

* the data were subjected to secondary examination, being included in the table above only data relating to children and young persons placed in public institutions in December of each year. For the years 2003 and 2004 have used only data from November, because December has not been identified. Were not included in the table those who are placed at foster parents, relatives, or in private centers.

Table 2. The situation of children who were abandoned/left in hospital units, in 2013

\begin{tabular}{|l|l|}
\hline $\begin{array}{l}\text { The number of children } \\
\text { abandoned in the maternity } \\
\text { hospitals and other medical units } \\
\text { in the January-December } 2013 \\
\text { of which: }\end{array}$ & 1449 \\
\hline Abandoned in maternity units & 915 \\
\hline Abandoned in pediatric units & 450 \\
\hline $\begin{array}{l}\text { Abandoned in other medical } \\
\text { units }\end{array}$ & 84 \\
\hline
\end{tabular}

Source: Ministry of Labour, Family and Social Protection - Child Protection Department, http://www.copii.ro/Statistici

\section{Results and discussion}

The measures taken after the 1990s have led to a decrease in the number of $0-3$ years children from the Public Placement Centers, until the year 2006. Later their number recorded a slight increase, which, however, remains on an annual basis (table 1 ).

If we analyze the situation of institutionalized children 0-3 years, compared to the total number of children in Public Orphanages, we can identify that, as a percentage, the number of children remains fairly constant within the range examined. Thus, in $2013,4 \%$ of the total number of children in public foster care institutions, was represented by children under 3 years old (Figure 1), and in 2003, a rate of $5 \%$ of the total number of children in public foster care institutions, was represented by children under 3 years (Figure 2). In 2006, when it was recorded the lowest number of institutionalized children in 
Public foster care Centers, they were in total 348, representing $1.6 \%$ of the total of 21.198 children from Public Centers (table 1).

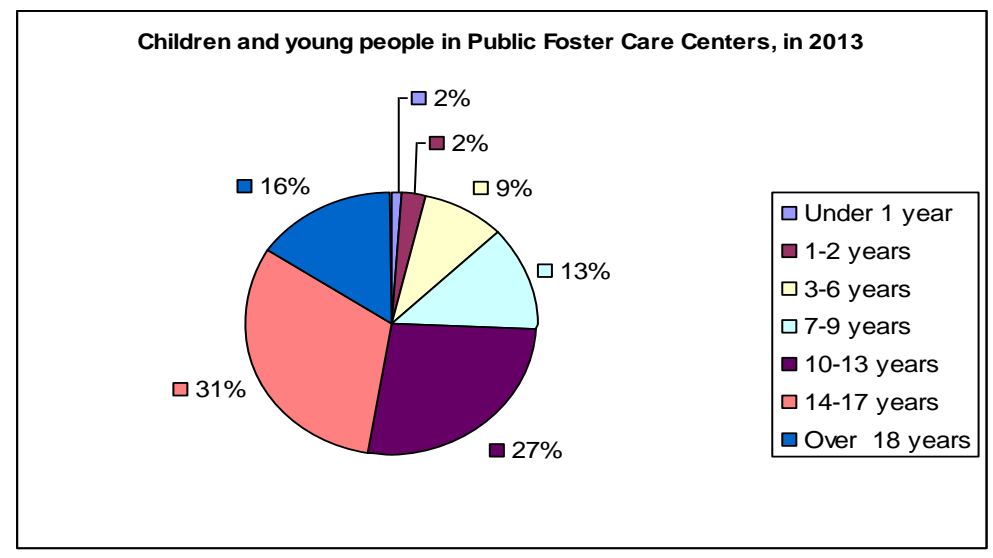

Figure 1 - Children and young people in Public Foster Care Centers, in 2013

A possible explanation of the fact that the percentage of children 0-3 years placed in Public Foster Care represent 5\% in 2003, and in 2013 has decreased to $4 \%$, after having fallen in 2006 to $1.6 \%$, would be the economic situation which has led to increased poverty, with the global economic crisis. Poverty continued to be a problem in Romania, but also the respond way to poverty, which often meant the abandonment of children, or more elegant said leaving them in hospital units, since from their birth.

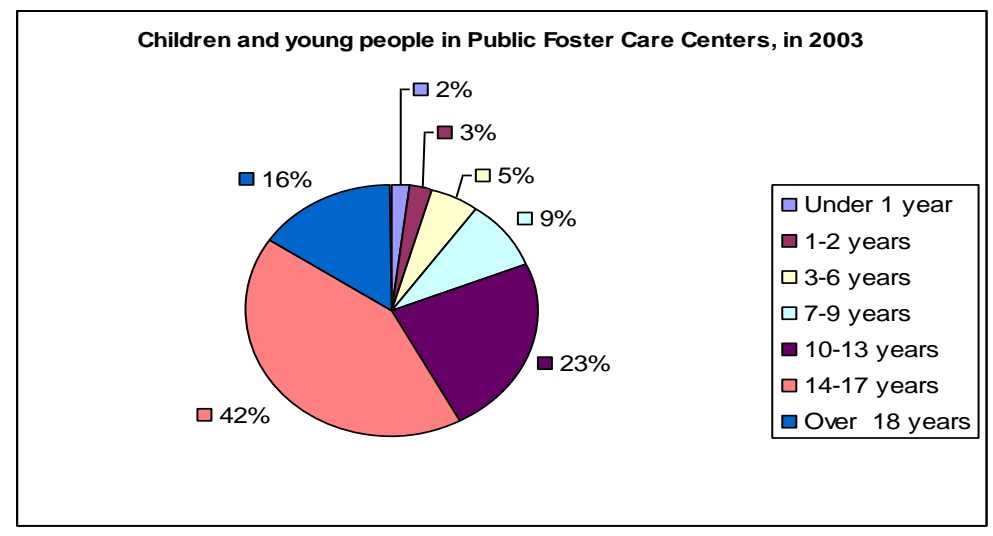

Figure 2 - Children and young people in Public Foster Care Centers, in 2003

Popescu, R. (2014). The Abandonment of Children with 0-3 years in Romania - Institutionalization and Issues. Logos Universality Mentality Education Novelty, Section: Social Sciemces, Year III, Issue 1, 2014, pp. 129-137 
It seems that the reaction of the population to face the challenge of the growth of one or more unwanted children, it was not to assume the responsibilities that came with the job of being parent. In Romania, the abandonment remains an extreme form of parental negligence, represent a rudimentary way of solving the problem of "unwanted children" or unaccepted for cultural or economic reasons and continues to be a common practice, "at least one out of one hundred children being abandoned in maternity" (Bonchiş, 2011: 383). Data about the abandonment of children in maternity, available on the website of the Ministry of Labour show that indeed there are still newborns leave in to the hospital immediately after birth. So in 2013 were left in maternity 915 , representing a rate of $63 \%$ of the total children leave temporarily in the Romanian hospitals (table 1).

Even the new-born abandoned in Maternities were placed in a foster family or to some different relatives, still some of them were placed with their siblings in different institutions. The data show that the number of children 0-3 years placed in public residential institution was 1508 in 2003, 1009 in 2004, 446 in 2005, after the law 272/2004 was published, 348 in 2006 and the number of steady increase being 698 in 2013 (table. 1).

In 2013 the new-born abandoned in maternities were 915 (table. 2) and only 273 children 0-1 years were in Public Residential Institution (table 1). Even the 273 children had siblings placed in institution or disabilities, the main goal should be for them to spend time in a family.

\section{Conclusions and proposals}

Study is a wake-up call about the scale of the phenomenon of abandonment of children and especially those aged 0-3 years and stresses the need to promote prevention of institutionalization of abandoned children and especially the need to support the family/mother in order to maintain family ties and to prevent abandon. Although Goffman excludes orphanages and Foster Places on the list of total institutions, he appreciates at the same time that "if the institution period is long may occur what was called acculturation characterized by dispossession of roles, the lack of boundaries between the spheres of everyday life, sleep, daily activities that take place in the same institution, the lack of personal belongings and the existence of strategies for adapting primary or secondary, solidarity, cooperation limited, situational withdrawal" (author translate from - Goffman, 2004: 63).

Abandoned children and institutionalized for long periods, integrate with difficulty in society, and many of them do not return into the origin family, the parents did not assume the parent role subsequent the abandonment, proof being the large number of young people in institutions. That is why long 
institutionalization must be prevented. It is also necessary to promote alternative measures of children protection in difficult situations, the Maternal Centre, Day Care Centre and also, Adoption. This would allow the parents to assume the role and parent responsibilities. Also, the Maternal Center is the only residential institution whose services can benefit child together with his mother, a fact that ensures a proper relationship between them designed to facilitate the formation of parental autonomy and preventing child abandonment 0-3 years.

Abandon prevention policies may be found in subsequent years increasing number of centers specialized in educating and working with parents/mother and child, like Maternal Centers, Day Centers and Centers/offices for counseling parents and children, and the success of these policies mean steady decrease in the number of children abandoned in hospitals or placed in public foster care centers.

\section{Acknowledgment}

The author reports no conflict of interest.

This paper was co-financed from the European Social Fund, through the Sectorial Operational Programme Human Resources Development 20072013, project number POSDRU/159/1.5/S/138907 "Excellence in scientific interdisciplinary research, doctoral and postdoctoral, in the economic, social and medical fields - EXCELIS", coordinator The Bucharest University of Economic Studies".

\section{REFERENCES}

Bonchiş, E. (Coord.). (2011). Familia şi rolul ei în educarea copilului, [Family and its role in children education]. Iaşi: Polirom.

Buțiu, C., (2011), Determinanţi ai ocupării grupurilor vulnerabile din perspectiva furnizorilor de servicii sociale - Studiu calitativ realizat în cadrul Grupului de Lucru, Alba Iulia, Universitatea „1 Decembrie 1918" [Determinants of employment of vulnerable groups from the perspective of providers of social services - Qualitative study carried aut in the framework of Working Group], accesed online in December 2013,

http://www.incluziunesociala.ro/upls/26 49743 Determinanti ai_ocu parii grupurilor vulnerabile.pdf

Chelcea, S. (2007). Metodologia cercetării sociale, metode cantitative și calitative, ediția a treia, [Social research methodology, quantitative and qualitative methods, third edition]. Bucureşti: Editura Economică.

Popescu, R. (2014). The Abandonment of Children with 0-3 years in Romania - Institutionalization and Issues. Logos Universality Mentality Education Novelty, Section: Social Sciemces, Year III, Issue 1, 2014, pp. 129-137 
Feng, W. (2005). Can China Afford to Continue Its One-Child Policy?. Analysis from the East-West Center, No. 77, accessed online in September 2014, http://scholarspace.manoa.hawaii.edu/handle/10125/3796

Gill, N. S., Roman Exposure of Infants, Selling cbildren -Human Alternative to Abandoning, Abortion or Killing, accessed online in August 2014, http://ancienthistory.about.com/od/familyanddailylife/qt/072707expo sure.htm

Goffman, E. (2004). Aqৃiluri. Eseuri despre situaţia socială a pacienților psibiatrici și a altor categorii de personae institutionalizate, [translated from Asylum: Essays on the social situation of mental patients and other inmates]. Iaşi: Polirom.

Greenwell, K. F., Reforma bunăstării copilului in România: abandon şi dęinstitutionalizare, 1987-2000, Child Welfare Reform in Romania: abandonment and des-institutionalization, 1987-2000], accessed online in August 2014,pdf.usaid.gov/pdf_docs/Pnacn657.pdf

Kligman, G. (2000). Politica Duplicității. Controlul Reproducerii în România lui Ceausescu, Procesul Comunismului, Bucureşti: Humanitas [The Politics of Duplicity. Controlling Reproduction in Ceausescu's Romania, 1998, University of California Press]

Marshall, P. J., Fox, N. A., \& the BEIP Core Group (2004). A comparison of the electroencephalogram between institutionalized and community children in Romania. Journal of Cognitive Neuroscience, 16(8), 1327-1338.

McLaughlin, K. A., Zeanah, C. H., Fox, N. A., \& Nelson, C. A. (2012). Attachment Security As A Mechanism Linking Foster Care Placement To Improved Mental Health Outcomes In Previously Institutionalized Children. Journal of Child Psychology \& Psychiatry, 53(1), 46-55. Accessed online in December 2013 http://www.bucharestearlyinterventionproject.org/Publications.html

Polvere, L. (2011). Youth Perspectives on Restrictive Mental Health Placement: Unearthing a Counter Narrative. Journal of Adolescent Research, 26(3), 318-343.

Segalen, M. (2011). Sociologia Familiei, [The Sociology of the Family]. Iaşi: Polirom.

*** Legea nr. 272 din 21 iunie 2004 privind protectia și promovarea drepturilor copilului, republicată în Monitorul Oficial nr. 159 din 5 martie 2014 [Law no 272 of 21 June 2004 on the protection and promotion of children's rights, republished in the Official Journal, no. 159 of 5 March 2014]

www.ziare.com/social/romani/copiii-parasiti-ai-romaniei-inca-in-umbraregimului-comunist-1223034.

Popescu, R. (2014). The Abandonment of Children with 0-3 years in Romania - Institutionalization and Issues. Logos Universality Mentality Education Novelty, Section: Social Sciemces, Year III, Issue 1, 2014, pp. 129-137 